\title{
Rehabilitation nutrition support for a hemodialysis patient with protein-energy wasting and sarcopenic dysphagia: a case report
}

\author{
Chiharu Uno ${ }^{1 *}$, Hidetaka Wakabayashi ${ }^{2}$, Keisuke Maeda $^{3}$ and Shinta Nishioka ${ }^{4}$
}

\begin{abstract}
Background: Patients with end-stage renal failure may exhibit sarcopenia and protein-energy wasting (PEW). We report a case of improvement in physical function, muscle mass, and muscle strength by management of rehabilitation nutrition in a maintenance hemodialysis patient with PEW and sarcopenia.

Case presentation: A 60-year-old man with an 8-year history of dialysis was admitted for pneumococcal meningitis. When he was transferred for rehabilitation 36 days following the onset, he was transferred to our hospital for rehabilitation and hemodialysis. On admission, energy intake was $1200 \mathrm{kcal} /$ day, via a nasogastric tube, due to sarcopenic dysphagia. He was diagnosed with PEW, based on results from a biochemical examination, physical examination, and his low dietary intake. His height, dry weight, body mass index, Mini Nutritional Assessment-Short Form, albumin, C-reactive protein, and Geriatric Nutritional Risk Index were $166 \mathrm{~cm}, 46.5 \mathrm{~kg}, 16$. $9 \mathrm{~kg} / \mathrm{m}^{2}, 1$ point, $2.1 \mathrm{~g} / \mathrm{dL}, 0.22 \mathrm{mg} / \mathrm{dL}$, and 63, respectively, indicating malnutrition. He was also diagnosed with sarcopenia because of low muscle mass, muscle strength, and physical function. Functional Independence Measure (FIM) was 58 points (motor 27, cognition 31). He was improved by a combination of rehabilitation including activities of daily living training, swallowing training, and nutrition management. Nutritional requirement was $1752 \mathrm{kcal} /$ day of energy and $55.5 \mathrm{~g} /$ day $(1.2 \mathrm{~g} / \mathrm{kg} /$ day $)$ of protein. Energy intake was added energy accumulation (300 kcal/day) to improve muscle mass and strength. On day 108, he was discharged to go home, he could walk outdoors, and his sarcopenic dysphagia improved.
\end{abstract}

Conclusion: Aggressive management of rehabilitation nutrition to increase dry weight may improve PEW and sarcopenic dysphagia in patients undergoing maintenance hemodialysis.

Keywords: Chronic kidney disease, Dry weight, Meningitis, Physical function, Sarcopenia

\section{Background}

Hemodialysis patients often have renal anemia, proteinenergy wasting (PEW), skeletal muscle loss, muscle weakness, skeletal muscle dysfunction, exercise intolerance, fatigue, decreased activity of daily living, and ultimately, declined quality of life (QOL) [1]. In addition to these consequences, hemodialysis patients tend to decrease their dietary intake, which causes sarcopenia [2]. Furthermore,

\footnotetext{
*Correspondence: chiharu83724@gmail.com

'Department of Nutrition, Sugiyama Hospital, 3-10 Yashirodai, Meito Ward,

Nagoya, Aichi Prefecture 465-0092, Japan

Full list of author information is available at the end of the article
}

metabolic and endocrine abnormalities (such as nonspecific inflammation; catabolism; metabolic acidosis; insulin resistance; and loss of amino acids, water-soluble vitamins, and trace elements associated with dialysis treatment) can lead to sarcopenia. It has been shown that declining physical function and malnutrition in dialysis patients are risk factors for cardiovascular events and poor prognosis. Sarcopenic dysphagia is caused by muscle mass reduction and muscle weakness of swallow-related muscles accompanying sarcopenia in the whole body. There is no obvious disease causing swallowing disorder, and it is thought that swallowing disorder while eating is caused by the addition of elements 
Table 1 Studies regarding nutritional interventions in hemodialysis patients with protein-energy wasting

\begin{tabular}{|c|c|c|c|c|c|c|c|}
\hline Case number & Author & Reported year & Reference & Subjects & Design & Period & $\begin{array}{l}\text { Results and clinical nutrition } \\
\text { significance }\end{array}$ \\
\hline 1 & Fouque et al. & 2008 & {$[4]$} & $\begin{array}{l}86 \mathrm{HD} \\
\text { patients }\end{array}$ & $\begin{array}{l}\text { Randomized controlled trial: ONS } \\
\text { vs control groups }\end{array}$ & 90 days & $\uparrow \mathrm{DEl}, \mathrm{DPI}, \mathrm{SGA}, \mathrm{QOL}$ \\
\hline 2 & Scott et al. & 2009 & {$[5]$} & $\begin{array}{l}88 \mathrm{HD} \\
\text { patients }\end{array}$ & $\begin{array}{l}\text { Randomized controlled trial: ONS } \\
\text { vs control groups }\end{array}$ & 90 days & $\uparrow$ albumin, QOL \\
\hline 3 & Moretti et al. & 2009 & {$[6]$} & $\begin{array}{l}49 \mathrm{HD} \\
\text { patients }\end{array}$ & $\begin{array}{l}\text { Randomized controlled trial: ONS } \\
\text { vs control groups }\end{array}$ & 1- year & $\uparrow n P C R$, albumin \\
\hline \multirow[t]{2}{*}{4} & \multirow[t]{2}{*}{ Malgorzewia et al. } & \multirow[t]{2}{*}{2011} & \multirow[t]{2}{*}[7]{} & \multirow{2}{*}{$\begin{array}{l}55 \text { HD } \\
\text { patients: } \\
\text { PEW (30) } \\
\text { Control } \\
\text { (25) }\end{array}$} & \multirow[t]{2}{*}{$\begin{array}{l}\text { Randomized controlled trial: ONS } \\
\text { vs control groups }\end{array}$} & \multirow[t]{2}{*}{90 days } & $\begin{array}{l}\uparrow \text { albumin, prealbumin in } 30 \\
\text { PEW patients }\end{array}$ \\
\hline & & & & & & & $\downarrow$ CRP, levels in both group \\
\hline 5 & Magnard J et al. & 2013 & {$[8]$} & $\begin{array}{l}50 \mathrm{HD} \\
\text { patients }\end{array}$ & $\begin{array}{l}\text { Randomized controlled trial: } \\
\text { exercise vs control group } \\
\text { (energy intake } 30-40 \mathrm{kcal} / \mathrm{kg} \text { of } \\
\text { ideal weight } / \mathrm{day} \text {, and protein } \\
\text { intake }>1.1 \mathrm{~g} / \mathrm{kg} \text { of ideal } \\
\text { weight } / \text { day) }\end{array}$ & 180 days & $\begin{array}{l}\uparrow \text { walk function, albumin and } \\
\text { prealbumin, body composition } \\
\text { (LTI, FTI), muscle strength, } \\
\text { postural stability, QOL (SF-36) }\end{array}$ \\
\hline 6 & Ravel VA et al. & 2013 & [9] & $\begin{array}{l}98,489 \\
\text { HD } \\
\text { patients }\end{array}$ & $\begin{array}{l}\text { Prospective cohort study: } \\
\text { reference level }(60 \text { to }<70 \mathrm{~g} / \mathrm{d}) \text {, } \\
\text { low protein nitrogen appearance } \\
(\text { PNA) levels }\end{array}$ & 8-years & $\uparrow$ risk of death \\
\hline 7 & $\begin{array}{l}\text { Rattanasompattikul } \\
\mathrm{M} \text { et al. }\end{array}$ & 2013 & {$[10]$} & $\begin{array}{l}84 \mathrm{HD} \\
\text { patients }\end{array}$ & $\begin{array}{l}\text { Pilot-feasibility, double-blind, ran- } \\
\text { domized, placebo-controlled trial: } \\
\text { ONS、PTX、ONS + PTX、con- } \\
\text { trol groups }\end{array}$ & 16 weeks & $\begin{array}{l}\uparrow \text { albumin (ONS、PTX、ONS + } \\
\text { PTX groups) }\end{array}$ \\
\hline 8 & Pasian C et al. & 2014 & [11] & $\begin{array}{l}48 \mathrm{HD} \\
\text { patients }\end{array}$ & Means of a dietetic intervention & 28 days & $\begin{array}{l}\uparrow \text { prealbumin, physical } \\
\text { autonomy, grip strength }\end{array}$ \\
\hline \multirow[t]{2}{*}{9} & \multirow[t]{2}{*}{ Mpio I et al. } & \multirow[t]{2}{*}{2015} & \multirow[t]{2}{*}{ [12] } & \multirow{2}{*}{$\begin{array}{l}49 \mathrm{HD} \\
\text { patients }\end{array}$} & \multirow{2}{*}{$\begin{array}{l}\text { Prospective study: optimization } \\
\text { of protein and energy intake in } \\
\text { the daily meals }\end{array}$} & \multirow[t]{2}{*}{ 1- year } & $\uparrow \mathrm{QOL}$ \\
\hline & & & & & & & $\downarrow$ mortality \\
\hline \multirow[t]{2}{*}{10} & \multirow[t]{2}{*}{ Hristea D et al. } & \multirow[t]{2}{*}{2016} & \multirow[t]{2}{*}{ [13] } & \multirow[t]{2}{*}{$\begin{array}{l}21 \mathrm{HD} \\
\text { patients }\end{array}$} & \multirow{2}{*}{$\begin{array}{l}\text { Pilot randomized controlled trial: } \\
\text { nutrition-exercise group vs Nutri- } \\
\text { tion group }\end{array}$} & \multirow[t]{2}{*}{6 months } & $\begin{array}{l}\uparrow \text { physical function (6MWT, } \\
\text { balance), QOL(SF-36) }\end{array}$ \\
\hline & & & & & & & $\begin{array}{l}\text { No change albumin, } \\
\text { prealbumin, CRP, BMI, lean- } \\
\text { and fat-tissue index, or quadri- } \\
\text { ceps force. Not to have the } \\
\text { potential to reverse PEW. }\end{array}$ \\
\hline 11 & Sohrabi Z et al. & 2016 & [14] & $\begin{array}{l}92 \mathrm{HD} \\
\text { patients }\end{array}$ & $\begin{array}{l}\text { A randomized, controlled, } \\
\text { nonblinded, parallel trial: vitamin } \\
\text { E-fortified Whey beverage vs } \\
\text { whey beverage vs vitamin E vs } \\
\text { control }\end{array}$ & 8 weeks & $\begin{array}{l}\text { Whey protein in the form of a } \\
\text { new fermented whey beverage } \\
\text { and vitamin E supplementation } \\
\text { may improve SGA score and } \\
\text { MIS in the short term. }\end{array}$ \\
\hline \multirow[t]{2}{*}{12} & \multirow[t]{2}{*}{$\begin{array}{l}\text { Martin-Alemañy G } \\
\text { et al. }\end{array}$} & \multirow[t]{2}{*}{2016} & \multirow[t]{2}{*}{ [15] } & \multirow[t]{2}{*}{$\begin{array}{l}36 \mathrm{HD} \\
\text { patients }\end{array}$} & \multirow[t]{2}{*}{$\begin{array}{l}\text { Randomized controlled trial: ONS } \\
+ \text { resistance exercise (RE) vs } \\
\text { control groups }\end{array}$} & \multirow[t]{2}{*}{90 days } & $\begin{array}{l}\uparrow \mathrm{BW}, \mathrm{BMI}, \mathrm{AMC}, \mathrm{TSF} \text {, fat mass } \\
\text { percentage, grip strength, } \\
\text { phase angle and albumin in } \\
\text { both group }\end{array}$ \\
\hline & & & & & & & $\downarrow$ prevalence of PEW \\
\hline \multirow[t]{2}{*}{13} & \multirow[t]{2}{*}{ Jo IY et al. } & \multirow[t]{2}{*}{2017} & \multirow[t]{2}{*}{ [16] } & \multirow[t]{2}{*}{$\begin{array}{l}42 \mathrm{HD} \\
\text { patients }\end{array}$} & \multirow[t]{2}{*}{$\begin{array}{l}\text { Intervention study: personalized } \\
\text { nutritional counseling }\end{array}$} & \multirow[t]{2}{*}{ 1- year } & $\begin{array}{l}\uparrow \text { DPI, albumin, and cholesterol } \\
\text { levels }\end{array}$ \\
\hline & & & & & & & $\downarrow$ body cell mass, fat free mass \\
\hline 14 & Hajira B et al. & 2017 & {$[17]$} & $\begin{array}{l}100 \mathrm{HD} \\
\text { patients }\end{array}$ & $\begin{array}{l}\text { Intervention study: dietary } \\
\text { counseling }\end{array}$ & 60 days & $\uparrow \mathrm{DEI}, \mathrm{DPI}, \mathrm{AC}, \mathrm{TSF}$, cholesterol \\
\hline 15 & Hosojima M et al. & 2017 & [18] & $\begin{array}{l}50 \mathrm{HD} \\
\text { patients }\end{array}$ & $\begin{array}{l}\text { Randomized, double-blind, cross- } \\
\text { over pilot trial: endosperm pro- } \\
\text { tein vs soy and casein proteins }\end{array}$ & 4 weeks & $\uparrow n \mathrm{nPCR}$ \\
\hline
\end{tabular}

Abbreviations: $A C$ arm circumference, $A M C$ midarm muscle circumference, $B C M$ body cell mass, $B M I$ body mass index, $C R P C$-reactive protein, $D E I$ dietary energy intake, DPI dietary protein intake, $F F M$ fat free mass, $H D$ hemodialysis, MIS malnutrition-inflammation score, $n P C R$ normalized protein catabolic rate, ONS oral nutritional supplements, PEW protein-energy wasting, PTX pentoxifylline, QOL quality of life, SF-36 36-Item 
Table 2 Summary of previous reports regarding protein-energy wasting and sarcopenic dysphagia

\begin{tabular}{|c|c|c|c|c|c|c|c|c|}
\hline Case number & Author & $\begin{array}{l}\text { Reported } \\
\text { year }\end{array}$ & Reference & Age & Sex & Primary disease & $\begin{array}{l}\text { Description of nutrition } \\
\text { therapy }\end{array}$ & $\begin{array}{l}\text { Evaluation of } \\
\text { sarcopenia }\end{array}$ \\
\hline 1 & $\begin{array}{l}\text { Mamo Y et } \\
\text { al. }\end{array}$ & 2003 & [19] & 18 years & Man & $\begin{array}{l}\text { Fibrocalcific pancreatic } \\
\text { diabetes }\end{array}$ & Unknown & None \\
\hline 2 & $\begin{array}{l}\text { Kalantar- } \\
\text { Zadeh K et } \\
\text { al. }\end{array}$ & 2009 & [20] & 54 years & Man & Type 2 diabetes and CKD & Unknown & None \\
\hline 3 & $\begin{array}{l}\text { Ikizler TA et } \\
\text { al. }\end{array}$ & 2013 & [21] & 74 years & Woman & $\begin{array}{l}\text { Gastrointestinal viral } \\
\text { disease, type } 2 \text { diabetes } \\
\text { and CKD }\end{array}$ & $\begin{array}{l}\text { Intravenous fluids and renal } \\
\text { specific oral nutritional } \\
\text { supplement }\end{array}$ & None \\
\hline 4 & $\begin{array}{l}\text { Wakabayashi } \\
\text { et al. }\end{array}$ & 2016 & [22] & 71 years & Man & Lung cancer & Rehabilitation nutrition & Yes \\
\hline 5 & Maeda et al. & 2016 & [23] & 80 years & Woman & $\begin{array}{l}\text { Age-related functional } \\
\text { decline }\end{array}$ & Rehabilitation nutrition & Yes \\
\hline 6 & Hashida et al. & 2017 & [24] & 76 years & Woman & Tongue cancer & Rehabilitation nutrition & Yes \\
\hline
\end{tabular}

Abbreviations: CKD chronic kidney disease

that accelerate sarcopenia, such as malnutrition, invasion, and waste for Elder of Flail [3]. Therefore, evaluation and treatment of PEW and sarcopenic dysphagia are very important issues in maintenance hemodialysis patients.

Nutritional therapies such as enteral nutrition, parenteral nutrition, and oral nutritional supplementation can be used to treat PEW [1]. A list of these studies, along with their reported nutritional outcomes, is provided in Table 1 [4-18]. The studies designed to establish the benefits of nutritional supplementation on the long-term improvements in overall nutritional status in hemodialysis patients with PEW have yielded encouraging results. The types of oral supplementations included regular meals, oral supplementation taken at home or during dialysis, and oral amino acid tablets. The duration of the treatment ranged from 1 month to over a year. The nutritional effects of these supplements are reported to improve nutritional indicators and body composition. In addition, reduction of mortality and improvement of PEW, physical function, and QOL have been reported.
Also, exercise interventions for dialysis patients are recommended because they improve exercise tolerance and ameliorate PEW, increase skeletal muscle mass and muscle strength, suppress protein catabolism, and, therefore, increase QOL. Previous studies have reported that PEW and sarcopenic dysphagia, which is characterized by a loss of swallowing function and generalized muscle mass, could be improved by rehabilitation and nutritional support. However, to our knowledge, there are few case reports on rehabilitation nutrition management for hemodialysis patients with PEW and sarcopenic dysphagia. The case reports of PEW and sarcopenic dysphagia to date are listed in Table 2 [19-24]. It is unknown whether rehabilitation nutrition management is effective in improving sarcopenic dysphagia in hemodialysis patients with PEW and sarcopenia.

We report a case of a maintenance hemodialysis patient with PEW and sarcopenic dysphagia, showing improvement in physical function, muscle mass, and strength as a result of rehabilitation nutrition management [25].

Table 3 Hospitalization present condition

\begin{tabular}{|c|c|c|c|c|c|}
\hline \multicolumn{2}{|c|}{ Hospitalization present condition } & \multicolumn{2}{|l|}{ Sarcopenia index } & \multicolumn{2}{|l|}{ Nutrition index } \\
\hline Body height & $166 \mathrm{~cm}$ & Physical function & Walking was impossible & MNA-SF & 1 point \\
\hline Dry weight & $46.5 \mathrm{~kg}$ & $\mathrm{CC}$ & $28 \mathrm{~cm}$ & GNRI & 63 \\
\hline BMI & $16.9 \mathrm{~kg} / \mathrm{m}^{2}$ & Grip strength & Right $15 \mathrm{~kg}$ & MIS & 21 points \\
\hline HDS-R & $27 / 30$ & & Left $18 \mathrm{~kg}$ & Biochemical test & \\
\hline MMSE & $25 / 30$ & Swallowing function & & Potassium & $3.5 \mathrm{mEq} / \mathrm{L}$ \\
\hline Dialysis condition & & MWST & 2 points & Phosphorus & $3.3 \mathrm{mg} / \mathrm{dL}$ \\
\hline Dialysis therapy & Hemodialysis & RSST & $2 / 30 \mathrm{~s}$ & Blood urea nitrogen & $41.6 \mathrm{mg} / \mathrm{dL}$ \\
\hline Dialysis time & $4 \mathrm{~h}$ & FILS & 3 & Creatinine & $7.38 \mathrm{mg} / \mathrm{dl}$ \\
\hline Dialyzer & VPS-18HA & Body function & & CRP & $0.22 \mathrm{mg} / \mathrm{dl}$ \\
\hline Blood flow rate & $200 \mathrm{ml} / \mathrm{min}$ & FIM & 58 points & Albumin & $2.1 \mathrm{~g} / \mathrm{dL}$ \\
\hline
\end{tabular}

Abbreviations: CC calf circumference, CRP C-reactive protein, FIM Functional Independence Measure, FILS Food Intake LEVEL Scale, GNRI Geriatric Nutritional Risk Index, MIS malnutrition-inflammation score, MMSE Mini Mental State Examination, MWST modified water swallow test Nutritional Risk Index, MNA-SF Mini Nutritional Assessment Short Form, RSST repetitive saliva swallowing test 


\section{Case presentation}

A 60-year-old man with an 8-year dialysis history as a result of immunoglobulin A nephropathy was admitted to an acute care hospital for generalized seizures due to pneumococcal meningitis and required mechanical ventilation. Before admission, he independently performed basic activities of daily living (ADL) and had neither central nervous system disease nor dysphagia. He was treated with antibiotic agents and was extubated after 10 days. After 36 days following the onset of symptoms, he was transferred to a long-term care hospital for rehabilitation and hemodialysis.

\section{Nutrition and physical assessment}

The condition observed at admission is shown in Table 3. Anthropometric measurement revealed the following: the body height was $166 \mathrm{~cm}$, dry body weight was $46.5 \mathrm{~kg}$, and body mass index (BMI) was $16.9 \mathrm{~kg} / \mathrm{m}^{2}$. The dry weight before onset was $49.5 \mathrm{~kg}$, with a weight loss of 6 . $1 \% /$ month. He had severe dysphagia, and Food Intake Level Scale (FILS) [26] was level 3 (swallowing training using a small quantity of food was performed). His score on the Mini Nutritional Assessment Short Form (MNASF) was 1-point, Geriatric Nutritional Risk Index (GNRI) was 63 , malnutrition-inflammation score was 21 points, and laboratory tests showed an albumin of $2.1 \mathrm{~g} / \mathrm{dL}, \mathrm{C}$ reactive protein of $0.22 \mathrm{mg} / \mathrm{dL}$; these indicated malnutrition. He was diagnosed with PEW based [27] on the results of a biochemical examination, physical examination, and his low dietary intake. Invasion caused by inflammation of meningitis, insufficient nutritional intake, and complications owing to chronic renal failure were the main causes of malnutrition.

He was diagnosed with severe sarcopenia because of decreased muscle mass (calf circumference $28 \mathrm{~cm}$ ), muscle strength (grip strength: right $15 \mathrm{~kg}$, left $18 \mathrm{~kg}$ ) , and physical function (walking was impossible) [28]. The causes of sarcopenia were considered to result from bed rest, invasion by meningitis, chronic renal failure, and low nutritional intake. Paralysis and decline of cognitive function were not observed. However, edema and pleural effusion were observed. He also received a diagnosis of possible sarcopenic dysphagia according to the relevant consensus diagnostic criteria because he presented with dysphagia and generalized sarcopenia. There was no obvious lesion suspected to be an organic disorder of the brain and because there was no history of paralysis and dementia (Mini Mental State Examination: 25 points), the cause of dysphagia was thought to be sarcopenia [29]. Functional Independence Measure (FIM) score was 58 points (motor domain score of 27, cognitive domain score of 31). Figure 1 shows the pathology-related figure of this case.

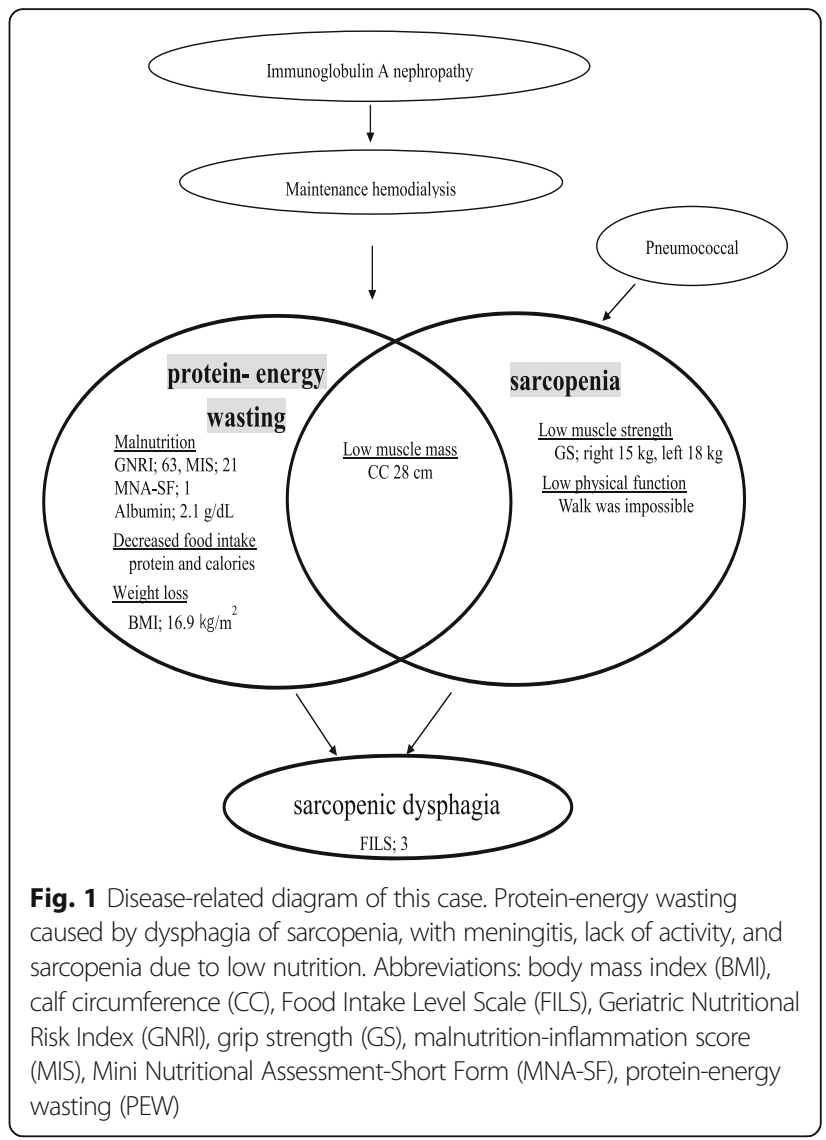

\section{Nutrition care management and outcome}

He wished to resume oral intake and be discharged home despite having severe dysphagia. Therefore, a multi-disciplinary team approach-including doctors, nurses, physiotherapists, a speech-language-hearing therapist, and registered dietitians-was used to improve $\mathrm{ADL}$, aid in the transition to oral intake of food, and accelerate discharge. The clinical course and intervention timeline are shown in Table 4 .

The energy requirement was set to $1752 \mathrm{kcal} /$ day as per the nutrition management plan during hospitalization. It was calculated using the Harris-Benedict equation [30], multiplied by the activity factor 1.2 and the stress factor 1.1 , added to the daily energy accumulation $(300 \mathrm{kcal} /$ day), to improve muscle mass and strength. Protein requirement was set at $55.8 \mathrm{~g}$ of protein $(1.2 \mathrm{~g} / \mathrm{kg}$ dry weight). Similar to the previous hospital, $1200 \mathrm{kcal} /$ day was administered from the nasogastric tube. The provided energy was gradually increased to $1500 \mathrm{kcal}$ on day 2 . On the 5 th day, the provided nutrition reached $1800 \mathrm{kcal}, 58.8 \mathrm{~g}$ of protein and $918 \mathrm{~mL}$ of water. After admission to our hospital, dry weight gradually decreased and reached $45.8 \mathrm{~kg}$ on the 15 th day. Thereafter, dialysis treatment was continued without significant decrease in blood pressure. 
Table 4 Trends in nutrition management and physical and mental functions

\begin{tabular}{|c|c|c|c|c|c|c|c|c|c|c|}
\hline \multicolumn{2}{|l|}{ Hospital day } & \multirow{2}{*}{$\begin{array}{l}\text { Admission } \\
\text { NG }\end{array}$} & On day 7 & On day 15 & $\begin{array}{l}\text { On day } \\
29\end{array}$ & On day 42 & On day 64 & On day 78 & \multirow{2}{*}{$\begin{array}{l}\text { On } \\
\text { day } 92\end{array}$} & $\begin{array}{l}\text { Discharge } \\
\text { On day } \\
108\end{array}$ \\
\hline \multirow{4}{*}{$\begin{array}{l}\text { Nutrition } \\
\text { management }\end{array}$} & Nutrition route & & \multicolumn{3}{|c|}{ NG and oral nutrition } & \multicolumn{4}{|l|}{ Oral nutrition } & \\
\hline & Nutrition menu & $\begin{array}{l}\text { Nutrient } \\
\text { for renal } \\
\text { failure }\end{array}$ & $\begin{array}{l}\text { Nutrient for } \\
\text { renal failure } \\
+ \text { Pureed }\end{array}$ & $\begin{array}{l}\text { Nutrient for } \\
\text { renal failure } \\
+ \text { Pureed }\end{array}$ & $\begin{array}{l}\text { Pureed } \\
+ \text { ONS }\end{array}$ & $\begin{array}{l}\text { Rice } \\
\text { porridge } \\
\text { and soft } \\
\text { food + ONS }\end{array}$ & $\begin{array}{l}\text { Diet for } \\
\text { dialysis (soft } \\
\text { and bite- } \\
\text { sized) }\end{array}$ & $\begin{array}{l}\text { Diet for } \\
\text { dialysis (soft } \\
\text { and bite- } \\
\text { sized) }\end{array}$ & $\begin{array}{l}\text { Diet } \\
\text { for } \\
\text { dialysis }\end{array}$ & $\begin{array}{l}\text { Diet for } \\
\text { dialysis }\end{array}$ \\
\hline & Energy (kcal) & 1200 & $1500+300$ & $1500+300$ & $\begin{array}{l}1400+ \\
300\end{array}$ & $1400+300$ & 1800 & 1800 & 2000 & 2000 \\
\hline & Protein (g) & 42.0 & 53.2 & 53.2 & 66.7 & 66.7 & 60.0 & 60.0 & 65.0 & 65.0 \\
\hline \multirow{4}{*}{$\begin{array}{l}\text { Nutrition } \\
\text { index }\end{array}$} & GNRI & 63 & - & - & 70 & - & 75 & - & 77 & 79 \\
\hline & MNA-SF (point) & 1 & - & - & - & - & - & - & - & 10 \\
\hline & $\mathrm{nPCR}$ (g/kg/day) & 0.5 & - & - & 0.69 & - & 0.8 & - & 0.86 & 0.89 \\
\hline & $\% C G R$ & 71 & - & - & 76 & - & 87 & - & 95 & 95 \\
\hline \multirow[t]{8}{*}{$\begin{array}{l}\text { Biochemical } \\
\text { examination }\end{array}$} & $\begin{array}{l}\text { Albumin } \\
(\mathrm{g} / \mathrm{dL})\end{array}$ & 2.1 & - & 2.3 & 2.6 & 2.9 & 2.9 & 2.9 & 3.0 & 3.1 \\
\hline & CRP $(\mathrm{mg} / \mathrm{dL})$ & 0.22 & - & - & 0.30 & - & 0.24 & - & 0.20 & 0.26 \\
\hline & Potassium (mg/dL) & 3.5 & - & 3.8 & 4.1 & 4.2 & 4.5 & 4.8 & 4.7 & 5.0 \\
\hline & $\begin{array}{l}\text { Phosphorus } \\
\text { (mg/dL) }\end{array}$ & 3.3 & - & 3.6 & 4.2 & 4.0 & 4.5 & 4.9 & 4.8 & 5.1 \\
\hline & $\begin{array}{l}\text { Sodium } \\
\text { (mEq/L) }\end{array}$ & 140 & - & 141 & 140 & 140 & 139 & 140 & 142 & 140 \\
\hline & $\begin{array}{l}\text { Blood urea nitrogen } \\
(\mathrm{mg} / \mathrm{dL})\end{array}$ & 41.6 & - & 42.8 & 43.9 & 49.8 & 57.5 & 62.5 & 62.2 & 70.5 \\
\hline & Creatinine (mg/dL) & 7.38 & - & 7.41 & 7.51 & 8.30 & 8.45 & 8.55 & 9.22 & 9.50 \\
\hline & $\begin{array}{l}\text { Cardiothoracic } \\
\text { ratio (\%) }\end{array}$ & 56.8 & - & - & 51.5 & - & 50.5 & - & 51.5 & - \\
\hline \multirow{6}{*}{$\begin{array}{l}\text { Physical } \\
\text { assessment }\end{array}$} & FIM (point) & 58 & - & - & - & - & 82 & - & 115 & - \\
\hline & $\begin{array}{l}\text { Grip strength; } \\
\text { right }(\mathrm{kg})\end{array}$ & 15 & - & - & 15 & - & 16 & - & 18 & - \\
\hline & $\begin{array}{l}\text { Grip strength; } \\
\text { left }(\mathrm{kg})\end{array}$ & 18 & - & - & 17 & - & 18 & - & 20 & - \\
\hline & FILS & 3 & - & - & 4 & - & 7 & 9 & 10 & - \\
\hline & Dry weight (kg) & 46.5 & 46.0 & 45.8 & - & 46.0 & 46.5 & - & 47.0 & 47.5 \\
\hline & $C C(\mathrm{~cm})$ & 28.0 & - & - & 28.2 & 28.4 & - & - & 28.8 & 29.1 \\
\hline
\end{tabular}

Abbreviations: CC calf circumference, CRP C-reactive protein, FIM Functional Independence Measure, FILS Food Intake Level Scale, GNRI Geriatric Nutritional Risk Index, MNA-SF Mini Nutritional Assessment Short-Form, NG nasogastric tube, $n P C R$ normalized protein catabolic rate, ONS oral nutritional supplements, \%CGR \% creatinine generation rate

On day 2, exercise training, physical activity training by physical therapist (PT), and swallowing training by the speech therapist (ST) began (PT: $20 \mathrm{~min} /$ day, ST: $20 \mathrm{~min} /$ day). On day 3, videoendoscopic examination (VE) of swallowing revealed disorders of bolus formation and transport. In addition, delayed swallowing reflex, a large amount of residuals in the epiglottic vallecula and pyriforms, and laryngeal penetration were also observed.

On day 7 , ingestion of pudding $(300 \mathrm{kcal})$ and thickened water began. On day 14, pureed food began to be offered only for one meal a day; from the 20th day, three meals were offered daily $(1400 \mathrm{kcal}+$ dietary supplement, $300 \mathrm{kcal}$ ). We continued physiotherapy, mainly focusing on lower limb muscular strength training and orthostatic exercises, and indirect swallowing training. The amount of enteral nutrition was modified based on physical activity and oral intake.

On day 42, the nasogastric tube was removed and rice porridge and soft food (combined with oral nutritional supplement) were started. VE on the 55th day showed no obvious larynx penetration and aspiration and improved throat clearance.

On day 81 , in addition to $\mathrm{PT}$-including walking training and stair ambulation-voluntary training was actively carried out. Therefore, we increased the provided energy to $2000 \mathrm{kcal}$ and $65 \mathrm{~g}$ protein. 
On day 108, he was discharged to go home, and he was able to walk outdoors. Dry weight increased to $47.5 \mathrm{~kg}$, and the MNA-SF increased to 10 points, while GNRI was 79 , indicating severe nutritional risk. The FIM score increased to 115 (+57) points (motor domain score of $81[+54]$, cognitive domain score of $34[+3])$, and bilateral handgrip strength improved (right $18[+3] \mathrm{kg}$, left 20 [+2] kg). His FILS level was 10, without developing pneumonia; sarcopenic dysphagia improved. He was no longer diagnosed with PEW because his dietary intake improved, although biochemical examination and physical examination did not show improvements. Walking ability improved, and handgrip strength showed a mild increase, although sarcopenia remains.

Ten months after discharge, he visits our hospital three times a week for maintenance dialysis.

\section{Discussion}

This case highlights two important issues with respect to nutritional intervention and management. Firstly, rehabilitation nutrition management aimed at increasing the dry weight, towards improving PEW in hemodialysis patients, may lead to improvement in physical function. Secondly, rehabilitation nutrition management may be useful in improving sarcopenic dysphagia in hemodialysis patients with PEW and sarcopenia.

Rehabilitation nutrition management aimed at increasing the dry weight in improving PEW in hemodialysis patients may lead to improvement in physical function. PEW is difficult to improve by nutritional supplementation alone because factors such as hyper catabolism accompanying dialysis, inflammation, loss of amino acids, insulin resistance, and endocrine abnormality may interfere with the treatment regimen [27]. Potential sources of sarcopenia, frailty, and protein-energy wasting in hemodialysis patients are shown in Fig. 2. The catabolism of protein and energy promotes not only fat loss but also protein loss, thus resulting in sarcopenia. Rehabilitation nutrition management evaluating sarcopenia is considered effective for improving physical functions. It is effective to raise awareness of sarcopenia, and early diagnosis and intervention are desired. Rehabilitation nutrition management improved physical function and facilitated the healing of pressure ulcers in a malnourished patient with type 2 diabetes. Based on this study, it may be useful to simultaneously perform nutritional support and rehabilitation for hemodialysis patients with PEW. We instituted nutrition control and rehabilitation by administering $38 \mathrm{kcal} / \mathrm{dry}$ weight/day for energy and $1.2 \mathrm{~g} / \mathrm{dry}$ weight/day for protein [3]. By sharing

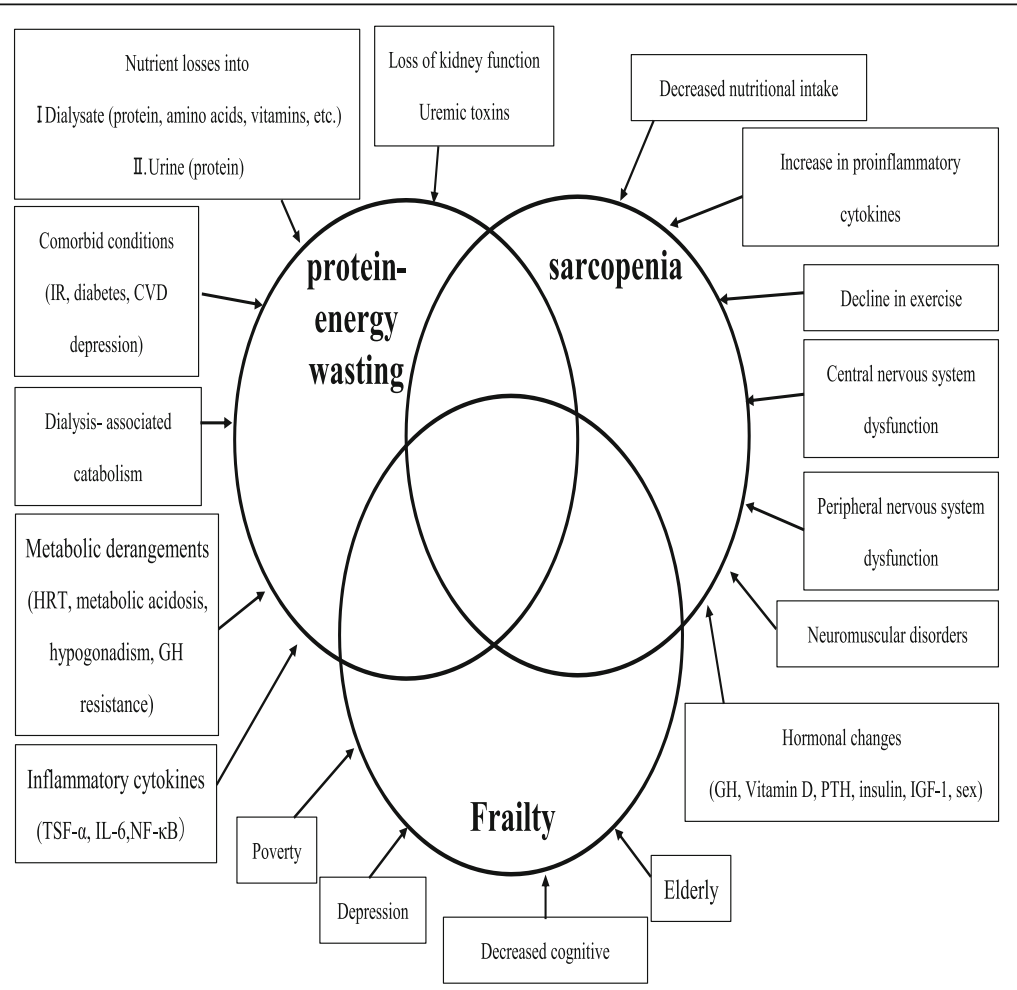

Fig. 2 Potential causes of sarcopenia, frailty, and protein-energy wasting in a hemodialysis patient. There are many factors in sarcopenia, frailty, and protein-energy wasting in hemodialysis patients, and these three factors often overlap. Abbreviations: cardiovascular disease (CVD), growth hormone (GH), hyperparathyroidism (HPT), insulin-like growth factor-1 (IGF-1), interleukin-6 (IL-6), insulin resistance (IR), nuclear factor-kappa B (NF-KB), parathyroid hormone (PTH), tumor necrosis factor-a (TSF-a) 
information on momentum and swallowing function, we carried out nutrition management considering the energy requirement for functional improvement. This resulted in improvement in nutritional status and physical function, which resulted in the patient's ability to orally ingest food and to walk outdoors.

Rehabilitation nutrition management may be useful in improving sarcopenic dysphagia in hemodialysis patients with PEW and sarcopenia. There is a correlation between sarcopenia and swallowing dysphagia [31]. Sarcopenic dysphagia is caused by muscle mass reduction and muscle weakness of whole body and swallowing [3]. In this case, sarcopenia was found in the whole body due to increased bed rest, parenteral nutrition intake, nutritional deficiency, and infiltration by meningitis, despite oral ingestion before artificial respiration. The patient in this case had risk factors for sarcopenic dysphagia, such as decreased skeletal muscle index, low independence of ADL, and low BMI [32]. Skeletal muscle loss is related to swallowing function and that sarcopenia and reconstructed tongue may cause sarcopenic dysphagia. In this case, the swallowing function was improved mainly by resistance training, food training, and nutrition improvement, and so, it was considered to be affected by sarcopenic dysphagia. Improvement in swallowing function was observed by carrying out nutrition management aimed at dry weight increase in maintenance dialysis patients and mainly based on resistance training.

\section{Conclusion}

Rehabilitation nutrition management aimed at increasing the dry weight in improving PEW, and sarcopenia in maintenance hemodialysis patients may lead to improvement in physical function and sarcopenic dysphagia. Further investigations are necessary to verify the effect of rehabilitation nutrition approach on maintenance dialysis patients with PEW and sarcopenia.

\section{Abbreviations}

ADL: Activities of daily living; BMI: Body mass index; FILS: Food Intake Level Scale; FIM: Functional Independence Measure; GNRI: Geriatric Nutritional Risk Index; MNA-SF: Mini Nutritional Assessment Short Form; PEW: Protein-energy wasting; PT: Physical therapist; QOL: Quality of life; ST: Speech therapist; VE: Videoendoscopic examination

\section{Acknowledgements}

Not applicable.

\section{Funding}

The authors declare that there is no funding related to this manuscript.

Availability of data and materials

The data and materials were all included in the manuscript.

\section{Authors' contributions}

All the authors have approved the manuscript and agree with submission to the esteemed journal. CU has participated in conception and design, acquisition of data, interpretation of data, drafting or revision of the manuscript, and approval of the final version of the manuscript. HW, KM, and SN have participated in conception and design, interpretation of data, drafting or revision of the manuscript, and approval of the final version of the manuscript.

\section{Ethics approval and consent to participate}

Written informed consent was obtained from the patient after a detailed explanation of the objectives of the study. The patient requested strongly that the report be published to rehabilitation nutrition management in dialysis patients. The patient provided informed consent for publication of this study, and the patient anonymity should be preserved.

\section{Consent for publication}

For publication of this case report, written agreement was obtained from the patient.

\section{Competing interests}

The authors declare that they have no competing interests.

\section{Publisher's Note}

Springer Nature remains neutral with regard to jurisdictional claims in published maps and institutional affiliations.

\section{Author details}

'Department of Nutrition, Sugiyama Hospital, 3-10 Yashirodai, Meito Ward, Nagoya, Aichi Prefecture 465-0092, Japan. 'Department of Rehabilitation Medicine, Yokohama City University Medical Center, 4-57 Urafune-chou, Minami Ward, Yokohama, Kanagawa Prefecture 232-0024, Japan. ${ }^{3}$ Palliative Care Center, Aichi Medical University, 1-1 Yazakokarimata, Nagakute, Aichi Prefecture 480-1195, Japan. ${ }^{4}$ Department of Clinical Nutrition and Food Service, Nagasaki Rehabilitation Hospital, 4-11 Ginya-machi, Nagasaki, Nagasaki Prefecture 850-0854, Japan.

Received: 16 November 2017 Accepted: 15 March 2018

Published online: 25 April 2018

\section{References}

1. Sabatino A, Regolisti G, Karupaiah T, Sahathevan S, Sadu Singh BK, Khor BH, et al. Protein-energy wasting and nutritional supplementation in patients with end-stage renal disease on hemodialysis. Clin Nutr. 2017;36:663-71.

2. Carrero JJ, Stenvinkel P, Cuppari L, Ikizler TA, Kalantar-Zadeh K, Kaysen G, et al. Etiology of the protein-energy wasting syndrome in chronic kidney disease: a consensus statement from the International Society of Renal Nutrition and Metabolism (ISRNM). J Ren Nutr. 2013;23:77-90.

3. Wakabayashi H. Presbyphagia and sarcopenic dysphagia: association between aging, sarcopenia, and deglutition disorders. J Frailty Aging. 2014;3:97-103.

4. Fouque D, McKenzie J, de Mutsert R, Azar R, Teta D, Plauth M, et al. Use of a renal-specific oral supplement by haemodialysis patients with low protein intake does not increase the need for phosphate binders and may prevent a decline in nutritional status and quality of life. Nephrol Dial Transplant. 2008;23:2902-10.

5. Scott MK, Shah NA, Vilay AM, Thomas J III, Kraus MA, Mueller BA. Effects of peridialytic oral supplements on nutritional status and quality of life in chronic hemodialysis patients. J Ren Nutr. 2009;19:145-52.

6. Moretti HD, Johnson AM, Keeling-Hathaway TJ. Effects of protein supplementation in chronic hemodialysis and peritoneal dialysis patients. J Ren Nutr. 2009;19:298-303.

7. Malgorzewicz S, Rutkowski P, Jankowska M, Debska-Slizien A, Rutkowski B, Lysiak-Szydlowska W. Effects of renalspecific oral supplementation in malnourished hemodialysis patients. J Ren Nutr. 2011;21:347-53.

8. Magnard J, Deschamps T, Cornu C, Paris A, Hristea D. Effects of a six-month intradialytic physical ACTlvity program and adequate NUTritional support on protein-energy wasting, physical functioning and quality of life in chronic hemodialysis patients: ACTINUT study protocol for a randomised controlled trial. BMC Nephrol. 2013;14:259. https://doi.org/10.1186/1471-2369-14-259.

9. Ravel VA, Molnar MZ, Streja E, Kim JC, Victoroff A, Jing J, et al. Low protein nitrogen appearance as a surrogate of low dietary protein intake is associated with higher all-cause mortality in maintenance hemodialysis patients. J Nutr. 2013;14:1084-92. 
10. Rattanasompattikul M, Molnar MZ, Lee ML, et al. Anti-Inflammatory and Anti-Oxidative Nutrition in Hypoalbuminemic Dialysis Patients (AIONID) study: results of the pilot-feasibility, double-blind, randomized, placebocontrolled trial. J Cachexia Sarcopenia Muscle. 2013:4:247-57.

11. Pasian C, Guebre-Egziabher F, Kalbacher E, Pommerol C, Fouque D. Nutritional care and clinical improvement in a renal ward: a pilot multimodal approach. Nephrol Ther. 2014;10:236-44.

12. Mpio I, Cleaud C, Arkouche W, Laville M. Results of therapeutics strategy of protein-energy wasting in chronic hemodialysis: a prospective study during 12 months. Nephrol Ther. 2015;11:97-103.

13. Hristea D, Deschamps T, Paris A, Lefrançois G, Collet V, Savoiu C, et al. Combining intra-dialytic exercise and nutritional supplementation in malnourished older haemodialysis patients: towards better quality of life and autonomy. Nephrology (Carlton). 2016;21:785-90.

14. Sohrabi Z, Eftekhari MH, Eskandari MH, Rezaianzadeh A, Sagheb MM. Intradialytic oral protein supplementation and nutritional and inflammation outcomes in hemodialysis: a randomized controlled trial. Am J Kidney Dis. 2016;68:122-30

15. Martin-Alemañy G, Valdez-Ortiz R, Olvera-Soto G, Gomez-Guerrero I, AguireEsquivel G, Cantu-Quintanilla G, et al. The effects of resistance exercise and oral nutritional supplementation during hemodialysis on indicators of nutritional status and quality of life. Nephrol Dial Transplant. 2016;31:1712-20.

16. Jo IY, Kim WJ, Park HC, Choi HY, Lee JE, Lee SM. Effect of personalized nutritional counseling on the nutritional status of hemodialysis patients. Clin Nutr Res. 2017;6:285-95.

17. Hajira B, Manzoor M, Samiullah M, Chawla RK. Effect of dietary counselling on the nutritional status of end-stage renal disease patients. J Pak Med Assoc. 2017:67:1327-30.

18. Hosojima M, Shimada H, Obi Y, Kuwahara S, Kaseda R, Kabasawa H, et al. A randomized, double-blind, crossover pilot trial of Rice endosperm protein supplementation in maintenance hemodialysis patients. Sci Rep. 2017;7(1): 18003. https://doi.org/10.1038/s41598-017-18340-8.

19. Mamo Y, Esayas S. Fibrocalcific pancreatic diabetes in a young Ethiopian man. Ethiop Med J. 2003;41:69-75.

20. Kalantar-Zadeh K, Derose SF, Nicholas S, Benner D, Sharma K, Kovesdy CP. Burnt-out diabetes: impact of chronic kidney disease progression on the natural course of diabetes mellitus. J Ren Nutr. 2009:19:33-7.

21. Ikizler TA. A patient with CKD and poor nutritional status. Clin J Am Soc Nephrol. 2013;8:2174-82.

22. Wakabayashi H, Uwano R. Rehabilitation nutrition for possible sarcopenic dysphagia after lung cancer surgery: a case report. Am J Phys Med Rehabil. 2016;95:e84-9

23. Maeda K, Akagi J. Treatment of sarcopenic dysphagia with rehabilitation and nutritional support: a comprehensive approach. J Acad Nutr Diet. 2016;116:573-7.

24. Hashida N, Shamoto H, Maeda K, Wakabayashi H, Suzuki M, Fujii T. Rehabilitation and nutritional support for sarcopenic dysphagia and tongue atrophy after glossectomy: a case report. Nutrition. 2017;35:128-31.

25. Wakabayashi H, Sakuma K. Rehabilitation nutrition for sarcopenia with disability: a combination of both rehabilitation and nutrition care management. J Cachexia Sarcopenia Muscle. 2014:5:269-77.

26. Kunieda K, Ohno T, Fujishima I, Hojo K, Morita T. Reliability and validity of a tool to measure the severity of dysphagia. The Food Intake LEVEL scale. J Pain Symptom Manag. 2013;46:201-6.

27. Fouque D, Kalantar-Zadeh K, Kopple J, Cano N, Chauveau P, Cuppari L, et al. A proposed nomenclature and diagnostic criteria for protein-energy wasting in acute and chronic kidney disease. Kidney Int. 2008;73:391-8.

28. Cruz-Jentoft AJ, Baeyens JP, Bauer JM, Boirie Y, Cederholm T, Landi F, et al. European working group on sarcopenia in older people. Sarcopenia: European consensus on definition and diagnosis report of the European working group on sarcopenia in older people. Age Ageing. 2010;39:412-23.

29. Mori T, Fujishima I, Wakabayashi H, Oshima F, Itoda M, Kunieda K, et al. Development, reliability, and validity of a diagnostic algorithm for sarcopenic dysphagia. JCSM Clinical Reports. https://doi.org/10.17987/jcsm-cr. v2i2.17.

30. Harris JA, Benedict FG. A biometric study of human basal metabolism. Proc Natl Acad Sci U S A. 1918:4:370-3.

31. Maeda K, Akagi J. Sarcopenia is an independent risk factor of dysphagia in hospitalized older people. Geriatr Gerontol Int. 2016;16:515-21.

32. Maeda K, Takaki M, Akagi J. Decreased skeletal muscle mass and risk factors of sarcopenic dysphagia: a prospective observational cohort study. J Gerontol A Biol Sci Med Sci. 2017;72:1290-4.

\section{Submit your next manuscript to BioMed Central and we will help you at every step:}

- We accept pre-submission inquiries

- Our selector tool helps you to find the most relevant journal

- We provide round the clock customer support

- Convenient online submission

- Thorough peer review

- Inclusion in PubMed and all major indexing services

- Maximum visibility for your research

Submit your manuscript at www.biomedcentral.com/submit
) Biomed Central 